\title{
Cell-Cell Adhesion Process
}

National Cancer Institute

\section{Source}

National Cancer Institute. Cell-Cell Adhesion Process. NCI Thesaurus. Code C19663.

Any cellular process in which one cell attaches to another via cell adhesion molecules. 